\title{
Profitability Analysis of Family-size Biogas Plant Installation in West Hararghe Zone, Oromia National Regional State, Ethiopia
}

\author{
Tale Gedefa ${ }^{1,}$, , Emebet Abera $^{2}$ \\ ${ }^{1}$ Department of Natural Resource Economics and Policy, College of Natural Resource and Environmental Science, Oda Bultum University, \\ Chiro, Ethiopia \\ ${ }^{2}$ Department of Management, College of Business and Economics, Oda Bultum University, Chiro, Ethiopia
}

Email address:

gedefa44@gmail.com (Tale G.), emebetabera49@gmail.com (Emebet A.)

${ }^{*}$ Corresponding author

\section{To cite this article:}

Tale Gedefa, Emebet Abera. Profitability Analysis of Family-size Biogas Plant Installation in West Hararghe Zone, Oromia National Regional State, Ethiopia. International Journal of Sustainable and Green Energy. Vol. 9, No. 2, 2020, pp. 45-52.

doi: $10.11648 /$ j.ijrse.20200902.14

Received: May 8, 2020; Accepted: May 25, 2020; Published: June 3, 2020

\begin{abstract}
Biogas technology, which converts biological waste into energy, is considered as an excellent tool to improve the lives, livelihoods, health, ecosystem and economy. In Ethiopia, biogas technology has been domesticated to improve the rural energy security and household's income by reducing their dependence on traditional biomass energy and chemical fertilizers. The profitability of biogas installation is rendered doubtful despite its numerous benefits and domestication efforts. Hence, this study aimed at evaluating the cost-benefit analysis and Profitability of biogas technology at household level in West Hararghe zone, Eastern Ethiopia. By using multistage sampling technique, cross-sectional data were collected from 105 systematically selected adopter households. The costs incurred and the benefits gained were analyzed using paired t-test. Payback Period (PBP), benefit cost ratio (BCR) and Net Present Value (NPV) were analyzed using different economic formula. The results indicated the most commonly domesticated plant is fixed dome biogas with volumes of $6 \mathrm{~m}^{3}$ and $8 \mathrm{~m}^{3}$. Investing $6 \mathrm{~m}^{3}$ biogas plant with subsidy ( 0.73 year) had short PBP than the $8 \mathrm{~m}^{3}$ plant $(0.97$ year). This implies, subsidy has been attracting households into biogas adoption. The BCR under assumption with subsidy was found to be 1.34 and 1.10 at $10 \%$ discount rate for $6 \mathrm{~m}^{3}$ and $8 \mathrm{~m}^{3}$ plants, respectively. Under both assumptions with and without subsidy, the NPV results for $6 \mathrm{~m}^{3}$ and $8 \mathrm{~m}^{3}$ biogas plant sizes turn out positive. In general, the results of PBP, BCR and NPV shown that the biogas investment is preferable and profitable for continuing the investment for the future.
\end{abstract}

Keywords: Biogas Energy, Biogas Plant Size, Profitability, Ethiopia

\section{Introduction}

The life of human being is highly dependent on energy consumption (IEA, 2011). In people's daily lives, energy provides essential benefits for cooking, heating, lighting, food production and storage, industrial production, education, and transportation. Energy, without any doubt, is the backbone of an economy. It is the most vital instrument for socio-economic development and has been recognized as one of the most important strategic commodities [28]. In modern times, no country has managed to substantially reduce poverty without increasing energy resources and its efficient utilization [27].

Today, in African countries, reliance on and appliances of traditional biomass energy could be a problem for sustainability of energy resource which leads to hold back economic development [19]. For many Sub-Saharan Africa (SSA) countries including Ethiopia, the energy consumption and demand is continuously increasing as development progresses and population growth is faster increasing. However, the modern domestic energy supply is disproportionate with its demand [4]. About $83 \%$ of the total population in SSA countries and $91 \%$ in least developed countries have no access to modern fuels [21]. Like other 
SSA counties, Ethiopia is highly dependent on traditional biomass for domestic energy (for cooking, heating and lighting); more than $93 \%$ of its population obtains energy from biomass (WHO, 2006). The interest of having access to modern and renewable energy in Ethiopia has been increasing as the rural community is suffering from energy crisis and ever increasing cost of chemical fertilizers [23]. Furthermore, biomass fuel is becoming scarce and household productivity is being affected by the reallocation of time and labor from yield bearing activities to the collection of biomass energy [3].

Rural domestic energy supply in Ethiopia is (virtually) entirely biomass based. In combination with the increasing pressure of the rural population, this has led to rapid depletion of natural resources and degradation of the environment in large areas of the country [11]. Firewood has been used to supply the needs for cooking in rural Ethiopia. Due to the ongoing deforestation and shortage of firewood, households need to look for other energy sources where a large number of people are use residues from agriculture (straw, manure) instead. However, both straw and manure also have a function in agriculture for soil improvement [29]. The use of chemical fertilizers becomes dominant and its volume is growing up annually with unaffordable prices. Ethiopia experiences an energy and environmental crisis due to the sustained reliance on woody biomass to satisfy its energy needs. This situation could be improved by using biogas [18]. The deployment of biogas energy as alternative energy source can have the potential to fill the gap in the energy needs of the rural community if it is effectively managed and appropriately utilized [20].

Biogas is the emerging bio-energy in the rural area of Ethiopia through biogas development program for potential households [12]. Biogas can be defined as a "mixture of methane and carbon dioxide produced by feeding animal dung (especially the manure of cattle) and water into an airtight underground tank, known as a digester, and allowing it to decompose. Biogas is a naturally occurring byproduct of decaying plant and animal material while bio-slurry is its byproduct. The biogas and bio-fertilizer produced can alleviate poverty, by improving health conditions, increasing crops productivity and saving working time and burden for women and children [13].

Technical issues like the availability of feedstock (water and cow dung), and existence of conducive temperature for operation of biogas production make Ethiopia a country with abundant potential for biogas installation [11]. Thus, Ethiopia has launched National Biogas Program (NBPE) in 2009, for dissemination of domestic biogas technology through a subsidy modality for at least one million households. Despite the numerous dissemination efforts, the economic potential of the technology has been largely remained indefinable, household are still doubtful to invest in it. Cost-benefit analysis is the most efficient and widely used tools for measuring whether any investment would be beneficial or not along with their environmental and social concern [8]. Therefore, the main objective of the study was to evaluate the cost of production and benefit generated and financial profitability of biogas installation across different plant sizes.

\section{Materials and Methods}

\subsection{Sample Size, Sampling Design and Method of Data Collection}

A multi-stage sampling technique was used for selecting sample households to be surveyed. First, the Habro district was selected purposively for being the home of the largest number of biogas installations during the survey time. Secondly, the three Kebeles ${ }^{1}$ adopting biogas technology were selected purposively based on the availability of biogas plants and the number of potential biogas adopting households relatively with higher experience in biogas energy generation and utilization. Finally, from three selected Kebeles' 105 biogas adopter households were selected randomly through simple lottery method. The lists of biogas adopter household heads' name were obtained from Habro District Water, Mine and Energy Office and the respective Kebele administrative officers.

Both qualitative and quantitative research techniques were applied in this study, including personal observations, focus group discussion, key informant interviews and questionnaire survey to gather primary data. Secondary data were collected from relevant published and unpublished sources like books, journal articles, CSA of Ethiopia, reports from the district energy office and Kebele administration offices [10].

\subsection{Methods of Data Analysis}

The collected raw data were coded, edited and organized using a Microsoft Excel. Then, the organized data were entered and analyzed using STATA version 13.1 at $\alpha=0.05$. The qualitative and quantitative data were analyzed by using analytical methods such as descriptive statistics, inferential statistics, and economic analysis. The monetary benefits of household biogas plant were analyzed by paired-samples ttest. The cost paid for installation and maintenance of biogas plant were analyzed using mean.

\subsubsection{Estimation of Costs and Benefits}

Estimation of cost and benefit is pre-request for profitability analysis. The costs associated with the biogas plant were quantified and estimated on the basis of the valuation of costs paid for biogas installation and maintenance. The cost of locally available material was valued at current price of local market, while those of tradable components were valued at the current retail market prices. Annual maintenance cost was estimated as:

$$
\mathrm{M}_{\mathrm{c}}=0.04 \mathrm{C}
$$

Where $\mathrm{M}_{\mathrm{c}}$ is maintenance cost, $\mathrm{C}$ is the total installation cost. In this study, the monetary benefits of biogas plant were

\footnotetext{
1 "Kebele" is the smallest administrative unit of Ethiopia, similar to a ward, a neighborhood or a localized and delimited group of people.
} 
computed only for the saved costs on firewood and kerosene substituted by biogas energy and saved costs on chemical fertilizer substituted by bio-slurry because of in the study area; there is no direct selling of biogas and bio-slurry in a market. The time saved due to biogas technology was not estimated because time saving as a result of redundant wood collection and cooking practices is categorized as an economic value (shadow prices), not monetary benefit [22].

The firewood consumptions/household in the study area were gathered in unit of bundle/week, and later converted into $\mathrm{kg} /$ week then $\mathrm{kg} / \mathrm{year}$. The monetary benefits of renewable energy like biogas technology can be evaluated on a random basis considering technology and its use. Thus, there is no universal method to evaluate the monetary benefits of biogas use, where research could follow a rational strategy (Islam, 2005). Accordingly, estimated by following the formulas of Bala and Hossain [6] as:

$$
\mathrm{AB}_{\mathrm{f}}=52.143\left(\mathrm{WF}_{\mathrm{cb}}-\mathrm{WF}_{\mathrm{ca}}\right) \mathrm{P}_{\mathrm{fw}}
$$

Where $\mathrm{AB}_{\mathrm{f}}$ represents average annual monetary benefits from firewood saved, 52.143 refers to 52.143 weeks/year, $\mathrm{WF}_{\mathrm{cb}}$ is represent the weekly firewood $(\mathrm{kg})$ consumption before adopting biogas technology and $\mathrm{WF}_{\mathrm{ca}}$ is the weekly firewood (kg) consumption after adopted biogas technology/household and $\mathrm{P}_{\mathrm{fw}}$, the current (2017) price of firewood $/ \mathrm{kg}$.

The data of kerosene consumption in the study area were counted in unit of bottle/week and later converted to litre (L). Consequently, cost saved from kerosene consumption was calculated by following the formulas of Bala and Hossain [6] as:

$$
\mathrm{AB}_{\mathrm{k}}=52.143\left(\mathrm{WK}_{\mathrm{cb}}-\mathrm{WK}_{\mathrm{ca}}\right) \mathrm{Pk}
$$

Where $\mathrm{AB}_{\mathrm{k}}$ represents the average annual monetary benefits from kerosene saved, 52.143 refers to 52.143 weeks/year, $\mathrm{WK}_{\mathrm{cb}}$ is represent weekly kerosene consumption (L) before adopting biogas technology and $\mathrm{WK}_{\mathrm{ca}}$, is the weekly kerosene consumption (L) after adopted biogas technology/household and $\mathrm{P}_{\mathrm{k}}$, the current (2017) price of kerosene/L.

Following Biswas and Lucas [7], the monetary benefit of bio-slurry was estimated by existing cost of chemical fertilizers used and computed as:

$$
\mathrm{AB}_{\mathrm{s}}=\left(\mathrm{ACh}_{\mathrm{b}}-\mathrm{ACh}_{\mathrm{a}}\right) \mathrm{p}_{c h}
$$

Where $\mathrm{AB}_{\mathrm{s}}$ represent the average annual benefits from bioslurry used, $\mathrm{ACh}_{\mathrm{b}}$ represent the annual amount of chemical fertilizers used/household before adopting biogas, $\mathrm{ACh}_{\mathrm{a}}$ is annual amount of chemical fertilizers used/household after adopted biogas and $\mathrm{p}_{\mathrm{ch}}$, is the farmers' association official price of current (2017) chemical fertilizers (This formula services for both DAP and Urea).

By combining the above formulae, the total annual monetary benefits of household biogas plants (TAB) could be estimated as follows:

$$
\mathrm{TAB}=\mathrm{AB}_{\mathrm{f}}+\mathrm{AB}_{\mathrm{k}}+\mathrm{AB}_{\mathrm{s}}
$$

\subsubsection{Profitability Analysis of Family-Size Biogas Plant Installation}

After cost and benefit were estimated, profitability is derivative from them. The economic tools like Benefit Cost ratio (BCR), Pay Back Period (PBP) and Net Present Value (NPV) were employed for the profitability analysis of the biogas plant installation and operation. A fixed dome biogas model (local name SINIDU, meaning "ready"), and $6 \mathrm{~m}^{3}$ and $8 \mathrm{~m}^{3}$ biogas plant sizes were selected for profitability analysis because they were the most commonly used model and size in the study area.

\section{i. Undiscounted Payback Period (UPBP)}

In this study, the annual profit is assumed to be equal therefore UPBP was used in the analysis because a constant rate is suitable for computations were annual benefits and maintenance costs are assumed uniform over the useful economic life of a plant. Thus, the UPBP can be calculated as:

$$
U P B p=\frac{C I}{A p}
$$

Where CI is total installation costs, AP is annual profit which is annual monetary benefits (biogas income) less annual maintenance costs.

\section{ii. Net Present Value (NPV)}

According to Mmopelwa [26] NPV is given by the following formula:

$$
\mathrm{NPV}=\sum_{\mathrm{t}=1}^{\mathrm{n}} \frac{\mathrm{B}_{\mathrm{t}}-\mathrm{C}_{\mathrm{t}}}{(1+\mathrm{r})^{\mathrm{t}}}
$$

Where $B_{t}$ is the benefit obtained from the biogas plant (biogas, bio-slurry) in each year, $\mathrm{C}_{\mathrm{t}}$ is the costs in each year, $\mathrm{t}$ is the expected useful economic life of a fixed-dome biogas plant from the present; $t=(1,2 \ldots 15)$ and $r$ is discount rate. $B_{t}$ and $C_{t}$ were assumed uniform over the expected useful economic life of biogas plant and discounted through all years. A useful economic life of a fixed-dome plant was assumed 15 years; based on quality of materials used and potential masons in the study area. A discount rate of $10 \%$ has been assumed based on the recent minimum lending interest rate for long-term; provided by Development Bank of Ethiopia (DBE) to farmers' association (MoFEC, 2016).

\section{iii. Benefits - Cost Ratio (BCR)}

The BCR is the ratio of benefits per unit of cost and estimated as follows [4]; Rahman and Kholilullah, 2017):

$$
B C R=\frac{T B_{t} /(1+r)^{t}}{T C_{t} /(1+r)^{t}}
$$

Where $\mathrm{TB}_{\mathrm{t}}$ is the total financial benefits obtained from the biogas plant (biogas, bio-slurry), $\mathrm{TC}_{\mathrm{t}}$ is total costs (installation costs and annual maintenance costs) of biogas plant. $\mathrm{TB}_{\mathrm{t}}$ and $\mathrm{TC}_{\mathrm{t}}$ were discounted only at the initial year of investment $(t=1)$ because it used to measures the present value of returns per money (ETB) invested. 


\section{Results and Discussion}

\subsection{Costs of Household Biogas Plants}

The costs of family-size biogas plant consist of digester installation costs and operational costs. The installation cost covers the materials used for bio-digester construction, such as cement, bricks, sand, and PVC pipe. The construction costs of biogas plants vary between different plant sizes they are often high relative to the income of farmers and other potential users. The high investment costs become a major barrier to technology uptake farmers. The economic assessment was based on digesters capital cost of the fixed dome model of $6 \mathrm{~m}^{3}$ and $8 \mathrm{~m}^{3}$.

Total costs of the most commonly used fixed-dome familysize biogas plants for $6 \mathrm{~m}^{3}$ and $8 \mathrm{~m}^{3}$ biogas plant sizes were computed as total installation costs in (Table 1) and maintenance costs in (Table 2), respectively. According to the survey data and secondary data obtained from Habro district water, mine and energy office of 2017 report some biogas owners acquired subsidy from the National Biogas Programme of Ethiopia (NBPE) while fewest are not obtain this access. Since 2010 NBPE has been endorsing a subsidy of ETB 6,000 for each household biogas plant. The subsidies (ETB 2,420) were considered in the form of costs of supply line including costs of biogas stove, biogas lamp with its accessory, valves (main gas, drain and gas tap) and connectors, and electric wires while ETB 3,580 was for biogas mason payment. The same subsidy was provided equally for all subsidized households and plant sizes. However, the cost paid for masons by households was already determined as per plant size (ETB 1,300 for $6 \mathrm{~m}^{3}$ and ETB 1,600 for $8 \mathrm{~m}^{3}$ ) starting from 2010 to the time of the execution of this study (2017). The other left costs are covered by adopter themselves. The average installation costs vary among households due to differences in types and costs of materials and labor used.

Table 1. Estimation of average installation costs of household biogas plants in Habro district.

\begin{tabular}{|c|c|c|c|c|c|}
\hline \multirow[t]{2}{*}{ Name of component } & \multicolumn{2}{|c|}{$\begin{array}{l}\text { Quantity of materials and/or } \\
\text { labor required for installation }\end{array}$} & \multirow[t]{2}{*}{$\begin{array}{l}\text { Unit price } \\
\text { (ETB) }\end{array}$} & \multicolumn{2}{|c|}{$\begin{array}{l}\text { Total cost of material /labor (ETB) } \\
\text { required for biogas plant size } \\
\text { installation }\end{array}$} \\
\hline & $6 \mathrm{~m}^{3}$ plant size & $8 \mathrm{~m}^{3}$ plant size & & $6 \mathrm{~m}^{3}$ plant size & $8 \mathrm{~m}^{3}$ plant size \\
\hline \multicolumn{6}{|l|}{ A. Civil construction cost } \\
\hline 1. Cement (bags, 50 kg) & 11 & 16 & 135 & 1,485 & 2,160 \\
\hline 2. Sand (barrows) & 12 & 18 & 75 & 900 & 1,350 \\
\hline 3. PVC pipe ( $6 \mathrm{~m}$ length and $70 \mathrm{~mm}$ diameter with its elbow) & 2 & 4 & 150 & 300 & 600 \\
\hline 5. Iron bar (6 m length and $8 \mathrm{~mm}$ diameter with binds) & 7 & 11 & 165 & 1,155 & 1,815 \\
\hline Transportation costs & & & & 210 & 240 \\
\hline Subtotal & & & & 4,395 & 6,510 \\
\hline \multicolumn{6}{|l|}{ B. Labor cost } \\
\hline 1. Mason cost (paid by adopters) & & & & 1,300 & 1,600 \\
\hline 2. Grave worker cost (barrows) & 12 & 15 & 90 & 1080 & 1,350 \\
\hline \multicolumn{6}{|l|}{ D. Subsidy } \\
\hline 1. Cost of supply line & & & & 2420 & 2420 \\
\hline 2. Mason (subsidized by NBPE) & & & & 3,580 & 3,580 \\
\hline Subtotal & & & & 6,000 & 6,000 \\
\hline F. Total installation costs $(C+D)$ & & & & 12,775 & 15,460 \\
\hline
\end{tabular}

Note: The installation costs were put in average because of amount and type of materials and labors used by different household were not the same. All figures in the Table were rounded off.

Table 2. Total installation and average annual maintenance costs of household biogas plants in Habro district.

\begin{tabular}{|c|c|c|c|}
\hline \multirow{2}{*}{ SN } & \multirow{2}{*}{ Name of Component } & \multicolumn{2}{|c|}{ Biogas plant size } \\
\hline & & $6 \mathrm{~m}^{3}$ & $8 \mathrm{~m}^{3}$ \\
\hline 1 & Total installation costs (ETB) & 12,775 & 15,460 \\
\hline 2 & average annual maintenance costs (ETB) & 511 & 619 \\
\hline 3 & Total Costs (ETB) $[1+2]$ & 13,286 & 16,079 \\
\hline
\end{tabular}

As the plant size is increased the installation cost is proportionally increased (costs increased proportionally between plant size and installation cost) (Table 2). This is consistent with Lutz and Howarth [22], as biogas plant size raises the installation cost per $\mathrm{m}^{3}$ of plant is increased. Nevertheless, this installation cost was not much high when compared with the 2008 baseline survey of NBPE in programme implementation document which is about ETB 13,000 for $6 \mathrm{~m}^{3}$ size (Eshete et al., 2006). The SNV household biogas plant cost varied around $\$ 400-600$ in 2010, depending on the market zone (NBP Cambodia, 2010). In the study area installation was based on local construction materials. In addition, no labor forces come from outside an adopter household member for excavation-work and other labor related work.

\subsection{Monetary Benefit of Family-size Biogas Plant Installation}

Regardless of the differences in accessibility and households' choices, a variety of household energy sources were utilized in the study areas. These energy sources were firewood, crop residues, kerosene and biogas. 


\subsubsection{Monetary Benefit from Firewood Consumption Replacement}

Firewood was utilized by the entire sample households for cooking. Some sample households sell firewood while others purchase trees or logs for firewood. According to Ministry of Agriculture [11], one bundle of firewood weights on average $32 \mathrm{~kg}$. On average, one bundle of firewood in the study area was about ETB 46.97 (at local retail market, January 27, 2017, when 1 USD $=22.46$ as National Bank of Ethiopia (NBE)); hence, the 2017 price of firewood was ETB 1.47/ kg.

The weekly average firewood consumption of the biogas adopter households before adopting biogas technology was $103.53 \mathrm{~kg} /$ household $(\mathrm{HH})$ and $107.29 \mathrm{~kg} / \mathrm{HH}$ for $6 \mathrm{~m}^{3}$ and 8 $\mathrm{m}^{3}$ plant sizes, respectively (Table 3 ). Whereas, it was 51.76 $\mathrm{kg} / \mathrm{HH}$ and $52.39 \mathrm{~kg} / \mathrm{HH}$ for $6 \mathrm{~m}^{3}$ and $8 \mathrm{~m}^{3}$ plant sizes, respectively, after adoption. As a result, adopter households were able to save firewood consumption by $2,699.44 \mathrm{~kg} / \mathrm{HH}$ and $2,862.65 \mathrm{~kg} / \mathrm{HH}$ for $6 \mathrm{~m}^{3}$ and $8 \mathrm{~m}^{3}$ biogas plants, respectively, annually (Table 3 ). Therefore, the annual monetary benefit from substitution of firewood by biogas energy for adopter households was ETB 3,968.18/HH and ETB $4208.09 / \mathrm{HH}$ for $6 \mathrm{~m}^{3}$ and $8 \mathrm{~m}^{3}$ plants, respectively, after adoption. A previous study conducted in rural Ethiopia reported a similar finding that, the average amount of firewood saved by the biogas adopter households was 3319 $\mathrm{kg} /$ year [14] and was $1730.1 \mathrm{~kg} /$ year with the equivalent amount of money saved is ETB 1903.11/year [2] after adoption of the technology. The difference was due to the biogas adopter households in the study area do not use charcoal and kerosene stove for cooking; they rather mostly use firewood for cooking.

Table 3. Weekly firewood consumption before and after biogas installation in Habro district.

\begin{tabular}{lllllll}
\hline Variable & Plant Size & Categories & Min & Max & mean \pm SD & p-value \\
\hline & \multirow{2}{*}{$6 \mathrm{~m}^{3}$} & Before adopting BT & 64 & 128 & $103.53 \pm 37.50$ \\
Firewood $(\mathrm{Kg})$ & & After adopted BT & 32 & 64 & $51.76 \pm 15.21$ & 9.135 \\
& \multirow{2}{*}{$8 \mathrm{~m}^{3}$} & Before adopting BT & 96 & 128 & $107.29 \pm 36.53$ & $0.000^{* * *}$ \\
& & After adopted BT & 32 & 64 & $52.39 \pm 15.04$ & 9.926 \\
\hline
\end{tabular}

Note: ***represents $1 \%$ level of significance, and BT= Biogas Technology

\subsubsection{Monetary Benefit from Kerosene Consumption Replacement}

In the study area, households use kerosene lamp for lighting purpose. Data on kerosene consumption was counted in a unit of bottle/week and was later converted to litre (1), 1 bottle $\approx 0.331$ or 3 bottles $\approx 11$. The local retail market price of 1 litre of kerosene was ETB 27 (when 1 US $\$=22.46$, January 27, 2017). Adopter households had completely replaced the kerosene consumption with biogas energy. Accordingly, they were able to save about $84.991 / \mathrm{HH}$ and $89.691 / \mathrm{HH}$ kerosene consumption annually for $6 \mathrm{~m}^{3}$ and 8 $\mathrm{m}^{3}$ plants, respectively (Table 4 ). Therefore, after adoption, substitution of kerosene with biogas energy generated an annual income of ETB 2,294.81/HH for $6 \mathrm{~m}^{3}$ and ETB $2,421.52 / \mathrm{HH}$ for the $8 \mathrm{~m}^{3}$ plant. Results from a previous study conducted in North Ethiopia reported a similar finding that the average amount of energy saved from kerosene replacement by the biogas adopter households was 10,538.9 $1 /$ year [24] and the maximum amount of money saved by the biogas user households from kerosene replacement was ETB 4493/year [9]. The difference was due to the market price of kerosene for different time and place, and also for the distance of market from households.

Table 4. Weekly kerosene consumption before and after biogas installation in Habro district.

\begin{tabular}{|c|c|c|c|c|c|c|c|}
\hline Variable & Plant size & Categories & Min & Max & $\operatorname{mean} \pm \mathrm{SD}$ & t-value & p-value \\
\hline \multirow{4}{*}{ Kerosene $(\ell)$} & \multirow{2}{*}{$6 \mathrm{~m}^{3}$} & Before adopting BT & 0.67 & 2.00 & $1.63 \pm 0.68$ & \multirow{3}{*}{17.202} & \multirow{3}{*}{$0.000 * * *$} \\
\hline & & After adopted BT & 0.00 & 0.00 & $0.00 \pm 0.00$ & & \\
\hline & \multirow{2}{*}{$8 \mathrm{~m}^{3}$} & Before adopting BT & 1.00 & 2.33 & $1.72 \pm 0.67$ & & \\
\hline & & After adopted BT & 0.00 & 0.00 & $0.00 \pm 0.00$ & 18.443 & $0.000 * * *$ \\
\hline
\end{tabular}

Note: $* * *$ represents $1 \%$ level of significance, and BT= Biogas Technology

\subsubsection{Monetary Benefit from Cost Saved of Chemical Fertilizers Used}

Households buy chemical fertilizers at the price of ETB $1,486 / 100 \mathrm{~kg}$ of DAP and ETB $1,374 / 100 \mathrm{~kg}$ of urea at the time of conducting this study. Regardless of plant size, adopters did not completely abandon the use of DAP and urea because the bio-slurry yielded from both plant sizes was inadequate to cover all farmlands. After adoption of the biogas technology, households were able to save 154.90 $\mathrm{kg} / \mathrm{HH} /$ year and $162.26 \mathrm{~kg} / \mathrm{HH} /$ year of DAP consumption from $6 \mathrm{~m}^{3}$ and $8 \mathrm{~m}^{3}$ plants, respectively (Table 5). Accordingly, adopters' annual monetary benefit when DAP was substituted by a bio-slurry was ETB 2,301.81/HH and
ETB 2,411.18/HH from $6 \mathrm{~m}^{3}$ and $8 \mathrm{~m}^{3}$ plants, respectively (Table 5). There was a high significance difference $(p<0.01)$ between DAP consumption of biogas adopter households before and after adoption of biogas technology from both 6 $\mathrm{m}^{3}$ and $8 \mathrm{~m}^{3}$ plants. The amount of urea saved by adopter households was $85.78 \mathrm{~kg} / \mathrm{HH} /$ year from $6 \mathrm{~m}^{3}$ and 94.60 $\mathrm{kg} / \mathrm{HH} /$ year from $8 \mathrm{~m}^{3}$ plants (Table 5). Accordingly, the annual monetary benefit adopters obtained from the cost spent on urea when substituted by a bio-slurry were ETB $1,178.62 / \mathrm{HH}$ and $1,299.80 / \mathrm{HH}$ from $6 \mathrm{~m}^{3}$ and $8 \mathrm{~m}^{3}$ plants, respectively. Annually $103.26 \mathrm{~kg}$ of chemical fertilizers was saved which is equivalent to annual monetary saving 717.66 $\mathrm{ETB} / \mathrm{HH} /$ year with average local rate of ETB $695 / 100 \mathrm{~kg}$ [3]. 
Results are highly dependent on slurry being effectively used as a source of fertilizer and on the price of the replaced energy source. Thus, the promotion of slurry use as fertilizer must be an integral part of a successful biogas program in Ethiopia [14].

Table 5. Annual chemical fertilizers consumption before and after biogas installation in Habro district.

\begin{tabular}{|c|c|c|c|c|c|c|c|}
\hline & Plant Size & Categories & Min & $\operatorname{Max}$ & $\operatorname{Mean} \pm$ SD & t-value & p-value \\
\hline \multirow{4}{*}{ DAP used (kg) } & \multirow{2}{*}{$6 \mathrm{~m}^{3}$} & Before adopting & 75 & 250 & $179.41 \pm 58.80$ & \multirow{3}{*}{15.521} & \multirow{3}{*}{$0.000^{* * *}$} \\
\hline & & After adopted & 0.00 & 100 & $24.51 \pm 40.15$ & & \\
\hline & \multirow{2}{*}{$8 \mathrm{~m}^{3}$} & Before adopting & 100 & 275 & $188.24 \pm 57.52$ & & \\
\hline & & After adopted & 0.00 & 125 & $25.98 \pm 29.14$ & \multirow[t]{2}{*}{16.668} & \multirow[t]{2}{*}{$0.000^{* * *}$} \\
\hline \multirow{4}{*}{ Urea used (kg) } & \multirow{2}{*}{$6 \mathrm{~m}^{3}$} & Before adopting & 50 & 50 & $104.41 \pm 45.75$ & & \\
\hline & & After adopted & 0.00 & 150 & $18.63 \pm 17.92$ & \multirow[t]{2}{*}{12.469} & \multirow[t]{2}{*}{$0.000^{* * *}$} \\
\hline & \multirow{2}{*}{$8 \mathrm{~m}^{3}$} & Before adopting & 75 & 175 & $115.19 \pm 45.02$ & & \\
\hline & & After adopted & 0.00 & 75 & $20.59 \pm 19.82$ & 13.735 & $0.000^{* * *}$ \\
\hline
\end{tabular}

Note: $* * *$ represents $1 \%$ level of significance

Table 6. Summary of annual monetary benefits from family-size biogas plants in Habro district.

\begin{tabular}{lll}
\hline Name of component & Biogas plant size \\
\cline { 2 - 2 } A. Average annual monetary benefits from biogas energy (ETB) & $\mathbf{6} \mathbf{~ m}^{\mathbf{3}}$ \\
1. Monetary benefit from firewood consumption replacement (ETB) & 3,968 \\
2. Monetary benefit from kerosene consumption replacement (ETB) & 2,295 \\
B. Average annual monetary benefits from bio-slurry (ETB) & \\
1. Monetary benefit from cost saved of DAP used (ETB) & 2,302 \\
2. Monetary benefit from cost saved of urea used (ETB) & 1,179 \\
Total annual monetary benefits from biogas plant (ETB) [A+B] & 9,744 \\
\hline
\end{tabular}

\subsection{Profitability of family-size Biogas Plants}

The profitability analysis was based on the financial costs spent and financial benefits gained for biogas investment. The profitability estimation in this study considers only the financial costs and benefits of biogas investment, not including some other external costs and benefits. The survey result showed that most installed biogas plants were subsidized whereas some are not. For this reason, the profitability of households' investment into biogas plant installation was evaluated as with a subsidy (base assumption) and without a subsidy. Under without subsidy situation, no external financial incentive was incorporated into the calculation of a biogas plant. Without subsidy estimation of a biogas plant offered the actual cost to be incurred for installation of a biogas plant. Particularly, households who for financial limitation could not adopt will be potential beneficiaries of subsidies. The subsidy estimation of a biogas plant provided that it plays vital role in increasing the adoption rate and attracts low income households to biogas technology adoption. Hence, for the profitability estimation of a biogas plant installation with a subsidy, the finance allocated (ETB 6000) was subtracted from the calculated cost of installation for each biogas plant.

\subsubsection{Undiscounted Payback Period (UPBP) Results}

Biogas plant with subsidy in both sizes repaid the original cost of investment in shorter period than biogas plant without subsidy. Investing $6 \mathrm{~m}^{3}$ biogas plant with subsidy had recovered the installation cost within 0.73 year $(8$ month and 22 day), while the $8 \mathrm{~m}^{3}$ plant had recovered within 0.97 year (11 month and 19 day) (Table 7). This implies that a household with a $6 \mathrm{~m}^{3}$ size would take few months to recover the original cost of investment through the annual net cash revenues it generates than the $8 \mathrm{~m}^{3}$ plant.

Under assumption of without subsidy, the payback period of $6 \mathrm{~m}^{3}$ biogas plant was shorter than $8 \mathrm{~m}^{3}$ biogas plant (Table 7). However, in both plants it takes a long period when compared with subsidized one to recover the initial investment costs, which were 1.38 years for $6 \mathrm{~m}^{3}$ and 1.59 years for $8 \mathrm{~m}^{3}$ biogas plant. Therefore, considering subsidy arrangement to biogas adopters, based on the UPBP results, the $6 \mathrm{~m}^{3}$ plant with a shorter period was more profitable than $8 \mathrm{~m}^{3}$ plants. This implies that, as the size of the biogas plant increases, the UPBP also increases. The $8 \mathrm{~m}^{3}$ biogas plant had higher installation costs than the $6 \mathrm{~m}^{3}$ plant.

Table 7. The results of UPBP with and without subsidy for different biogas plant size.

\begin{tabular}{llll}
\hline \multirow{2}{*}{ SN } & \multirow{2}{*}{ Undiscounted Payback Period (Years) } & \multicolumn{2}{l}{ Biogas plant size } \\
\cline { 3 - 4 } & & $\mathbf{6} \mathbf{~ m}^{\mathbf{3}}$ & $\mathbf{8 \mathbf { ~ m } ^ { \mathbf { 3 } }}$ \\
\hline 1 & With subsidy & 0.73 & 0.97 \\
2 & Without subsidy & 1.38 & 1.59 \\
\hline
\end{tabular}

The payback period for similar sizes was 5.35 years in Pakistan [5]. Benefits from biogas plants covered all costs.

\subsubsection{Net Present Value (NPV) Results}

The NPV is a way of comparing the present and future values of cash flows by using the discount rate and a time constraint. Under both assumptions with and without subsidy, the NPV results for $6 \mathrm{~m}^{3}$ and $8 \mathrm{~m}^{3}$ biogas plant sizes turn out positive (Table 8). Positive NPV means that the biogas investment is preferable and profitable for continuing the 
investment for the future. It implies that the cost invested for the respective plant size was smaller than the income generated. The NPV for $6 \mathrm{~m}^{3}$ biogas plant was ETB 56508 and ETB 55674 for $8 \mathrm{~m}^{3}$ under assumption with subsidy while the NPV under assumption without subsidy was ETB 51053 for $6 \mathrm{~m}^{3}$ biogas plant and ETB 50219 for $8 \mathrm{~m}^{3}$ plant (Table 8). This implies that, a $6 \mathrm{~m}^{3}$ biogas plant; under both assumptions with and without subsidy would be more sensitive to changes in financial parameters and profitable than the $8 \mathrm{~m}^{3}$ size. The biogas investment without subsidy in both $6 \mathrm{~m}^{3}$ and $8 \mathrm{~m}^{3}$ plants are less viable than of biogas investment with subsidy (Table 8).

Table 8. The results of NPV with subsidy and without subsidy for different biogas plant size.

\begin{tabular}{|c|c|c|c|}
\hline \multirow{2}{*}{ SN } & \multirow{2}{*}{ Net present Value (ETB) } & \multicolumn{2}{|c|}{ Biogas plant size } \\
\hline & & $6 \mathrm{~m}^{3}$ & $8 \mathrm{~m}^{3}$ \\
\hline 1 & With subsidy & 56508 & 55674 \\
\hline 2 & Without subsidy & 51053 & 50219 \\
\hline
\end{tabular}

This result is in line with Gwavuya et al. [14] that the small sizes of biogas plant in Ethiopia were more profitable than the large sizes. Kabir et al. [17] showed that under assumption with subsidy, biogas users in Bangladesh obtain better financial results compared to assumption without subsidy. The positive net present values of $\$ 4500$ for $8 \mathrm{~m}^{3}$, showed that biogas systems were economically viable in Uganda [30]. Results show that households in rural areas largely collect their own fuel, with female household members being mainly responsible for the chore. By investing in biogas plants, households could save time and energy, and have a supply of slurry that can be used as fertilizer in agricultural production. A cost-benefit analysis of biogas plants yields positive net present values for households collecting their own energy sources. Even higher net present values are obtained for households purchasing all of their energy needs; these households stand to gain significantly from the financial benefits of energy cost savings with biogas technology [14].

\subsubsection{Benefit - Cost Ratio (BCR) Results}

The BCR was used to measures the present value of returns per ETB invested. The financial analysis of BCR under assumption with subsidy was found to be 1.34 and 1.10 at $10 \%$ discount rate for $6 \mathrm{~m}^{3}$ and $8 \mathrm{~m}^{3}$ plants, respectively (Table 9). This means that the investment in the biogas by ETB 1 would provide return (profit) of 34 cents from $6 \mathrm{~m}^{3}$ and 10 cents from $8 \mathrm{~m}^{3}$ plants. Therefore, the use of biogas plant was more profitable as cost associated with it is outweighed by the benefit obtained. The results of BCR also showed $6 \mathrm{~m}^{3}$ biogas plant was more financially profitable than $8 \mathrm{~m}^{3}$ plant. In both biogas plant sizes, biogas investment was more financially profitable under the assumption with subsidy while it was unprofitable under the assumption without subsidy in the initial year (Table 9). We found BCR or rate of return to be 1.34 and 0.74 which is about $10 \%$ (Table 9).
Table 9. The results of BCR with subsidy and without subsidy for different biogas plant size.

\begin{tabular}{llll}
\hline \multirow{2}{*}{ SN } & \multirow{2}{*}{ Benefit - cost ratio (BCR) } & \multicolumn{2}{l}{ Biogas plant size } \\
\cline { 3 - 4 } & & $\mathbf{6} \mathbf{~ m}^{\mathbf{3}}$ & $\mathbf{8 \mathbf { ~ m } ^ { \mathbf { 3 } }}$ \\
\hline 1 & With subsidy & 1.34 & 1.10 \\
2 & Without subsidy & 0.74 & 0.64 \\
\hline
\end{tabular}

According to Abbas et al [1] BCR of biogas plants was greater than 1 at all levels. The BCR of $6 \mathrm{~m}^{3}$ biogas plants was 1.56 for substitution of fuel only, which made them feasible even for the sake of getting energy only. Rates of return of about $18 \%$ are reported for a $6 \mathrm{~m}^{3}$ plant of similar design in Pakistan [1]. Adopting biogas technology is more profit for households which purchase all of their firewood. Households that use dung for combustion stand to benefit more than households collecting firewood by adopting biogas technology.

\section{Conclusion and Recommendations}

Investing Biogas technology among the rural households of Habro district of Ethiopia was financially profitable. The total costs of biogas investment was not much high when compared with other energy technology. Adoption of biogas technology plays a substantial role in reduction of firewood, kerosene and chemical fertilizers consumptions, which results enhancing households' income by saving the costs spent on them. On the basis of costs and benefits found in this study, it can be concluded that, the financial analysis of 6 $\mathrm{m}^{3}$ and $8 \mathrm{~m}^{3}$ plant sizes that are installed with subsidy have big NPV values, UPBP of less than one year and BCR values of greater than one, indicates that as they are financially profitable at $10 \%$ discount rate. Nevertheless, for both $6 \mathrm{~m}^{3}$ and $8 \mathrm{~m}^{3}$ plant sizes that are installed without subsidy have small NPV values and UPBP value is greater than one year, which shows less financially profitable. Comparatively, the 6 $\mathrm{m}^{3}$ size was highly profitable than the $8 \mathrm{~m}^{3}$ size. In general, the results of UPBP, BCR and NPV shown that the biogas investment is preferable and profitable for continuing the investment for the future. Therefore, based on the above conclusion the following recommendations are drawn:

1) The study result found that, most of people are motivated by subsidy to engage the low-income households in adoption; biogas is attractive under the present subsidy scheme. Similarly, the investment is more financially profitable under assumption with subsidy than that of without subsidy. Therefore, the subsidy that provided by NBPE and others should be continued for a certain period, until the households familiarize to biogas technology.

2) The study specifically focused on the fixed dome plant model, and $6 \mathrm{~m}^{3}$ and $8 \mathrm{~m}^{3}$ plant sizes and estimated only their financial profitability at household level. Therefore, further research works should focus on others biogas model and sizes, economic profitability at medium and large level.

\section{Acknowledgements}

The authors are grateful to thank Habro District Mine, 
Water and Energy Office and experts, respondent households, group discussants, and key informants for their willingness to contribute to the study by being the source of necessary data and information.

\section{References}

[1] Abbas, Q., \& Awan, S. H. (2017). Impact of organizational politics on employee performance in public sector organizations. Pakistan Administrative Review, 1 (1), 19-31.

[2] Alemneh, Z. (2011). The contribution of biogas production from cattle manure at household level for forest conservation and soil fertility improvement. Unpublished MSc Thesis, Science Faculty, Addis Ababa University.

[3] Amare, Z. Y. (2014). The role of Biogas Energy Production and Use in Greenhouse Gas Emission Reduction; the case of Amhara National Regional State, Fogera District, Ethiopia. benefits $1(5)$.

[4] Amigun, B., Sigamoney, R. \& von Blottnitz, H. (2008). Commercialisation of biofuel industry in Africa: a review. Renewable and Sustainable Energy Reviews 12 (3): 690-711.

[5] Ansari, M. S. Khan, M. S. Haider, A. Ahmad, M. A. Ahmed, (2011) A study on economic feasibility of biogas plant for a small town, Sci. Int. 23, 325e326.

[6] Bala, B. \& Hossain, M. (1992). Economics of biogas digesters in Bangladesh. Energy 17 (10): 939-944.

[7] Biswas, W. K. \& Lucas, N. (1997). Economic viability of biogas technology in a Bangladesh village. Energy 22 (8): 763-770.

[8] Chakrabarty, S., Boksh, F. M. \& Chakraborty, A. (2013). Economic viability of biogas and green self-employment opportunities. Renewable and Sustainable Energy Reviews 28: 757-766.

[9] Claudia, B. \& Addis, Y. (2011). Survey of biogas plants in four regional states of Ethiopia. SNV Ethiopia.

[10] CSA (2013). Population Projection of Ethiopia for all regions at district level (2014-2017). Central Statistics Agency (CSA), Addis Ababa, Ethiopia.

[11] Eshete, G., Sonder, K. \& ter Heegde, F. (2006). Report on the feasibility study of a national programme for domestic biogas in Ethiopia. SNV Netherlands Development Organization: Addis Ababa, Ethiopia.

[12] Gabisa, E. W. \& Gheewala, S. H. (2019). Potential, environmental, and socio-economic assessment of biogas production in Ethiopia: The case of Amhara regional state. Biomass and Bioenergy 122: 446-456.

[13] Garfí, M., Ferrer-Martí, L., Velo, E. \& Ferrer, I. (2012). Evaluating benefits of low-cost household digesters for rural Andean communities. Renewable and Sustainable Energy Reviews 16 (1): 575-581.

[14] Gwavuya, S., Abele, S., Barfuss, I., Zeller, M. \& Müller, J. (2012). Household energy economics in rural Ethiopia: A cost-benefit analysis of biogas energy. Renewable Energy 48: 202-209.

[15] IEA (2011). “World Energy Model — Methodology And
Assumptions", International Energy Agency, Paris Cedex, France.

[16] Islam A. K. M. S., 2005. Status of Renewable Energy Technologies in Bangladesh, ASESCO Science and Technology Vision, 1 Pp. 51

[17] Kabir, H., Palash, M. \& Bauer, S. (2012). Appraisal of domestic biogas plants in Bangladesh. Bangladesh Journal of Agricultural Economics 35 (454-2016-36351): 71.

[18] Kamp, L. M. \& Forn, E. B. (2016). Ethiopia' s emerging domestic biogas sector: Current status, bottlenecks and drivers. Renewable and Sustainable Energy Reviews 60: 475-488.

[19] Karekezi, S. (2002). Renewables in Africa-meeting the energy needs of the poor. Energy Policy 30 (11-12): 10591069 .

[20] Kelebe, H. E., Ayimut, K. M., Berhe, G. H. \& Hintsa, K. (2017). Determinants for adoption decision of small scale biogas technology by rural households in Tigray, Ethiopia. Energy Economics 66: 272-278.

[21] Legros, G., Havet, I., Bruce, N., Bonjour, S., Rijal, K. \& Takada, M. (2009). The energy access situation in developing countries: a review focusing on the least developed countries and Sub-Saharan Africa. World Health Organization and UNDP.

[22] Lutz, D. A. \& Howarth, R. B. (2015). The price of snow: albedo valuation and a case study for forest management. Environmental Research Letters 10 (6): 064013.

[23] Mengistu, M. G., Simane, B., Eshete, G. \& Workneh, T. S. (2016a). The environmental benefits of domestic biogas technology in rural Ethiopia. Biomass and Bioenergy 90: 131138 .

[24] Mengistu, M. G., Simane, B., Eshete, G. \& Workneh, T. S. (2016b). Factors affecting households' decisions in biogas technology adoption, the case of Ofla and Mecha Districts, northern Ethiopia. Renewable Energy 93: 215-227.

[25] Ministry of Finance and Economic Development. 2016. Growth and Transformation Plan Annual Progress Report for F. Y. 2014/15

[26] Mmopelwa, G. (2006). Economic and financial analysis of harvesting and utilization of river reed in the Okavango Delta, Botswana. Journal of environmental management 79 (4): 329335.

[27] Rao, P. S. C., Miller, J. B., Wang, Y. D. \& Byrne, J. B. (2009) Energy-microfinance intervention for below poverty line households in India. Energy Policy 37 (5): 1694-1712.

[28] Sahir, A. H. Qureshi, (2007) Specific concerns of Pakistan in the context of energy security issues and geopolitics of the region, Energy Policy 35, 2031 e2037.

[29] Tucho, G. \& Nonhebel, S. (2015). Bio-wastes as an alternative household cooking energy source in Ethiopia. Energies 8 (9): 9565-9583.

[30] Walekhwaa, D. Larsb, J. Mugishaa, (2014). Economic Viability of Biogas Energy Production from Family-sized Digesters in Uganda.

[31] WHO (2006). UNAIDS: Air quality guidelines: global update 2005. World Health Organization. 